\title{
Migration to the US among rural Puerto Ricans who inject drugs: influential factors, sources of support, and challenges for harm reduction interventions
}

\author{
R. Abadie ${ }^{1 *}$ (D, P. Habecker ${ }^{1}$, C. Gelpi-Acosta ${ }^{2}$ and K. Dombrowski ${ }^{1}$
}

\begin{abstract}
Background: While PWID of Puerto Rican origin have been migrating to the US for decades, the range of factors influencing their migration to the US and the resources they draw on to do so are not well understood. This is particularly true for rural Puerto Rican PWID, and the present study is the first empirical research to document migration patterns among this population. The specificities of their migration raise important challenges that need to be documented in order to implement more effective harm reduction policies at home (Puerto Rico) and abroad (US).

Methods: This paper draws from data obtained employing a modified NHBS survey which was administered to $(N=296)$ PWID in four rural municipalities of Puerto Rico with participants 18 years or older. The primary dependent variables for this paper are the number of times a person has lived in the continental US, and if they are planning on moving to the continental US in the future.

Results: Findings suggest that $65 \%$ of the sample reported ever lived in the US and that $49 \%$ are planning on moving in the future. The number of times living in the US is associated with higher education and older age, but not with self-reported positive HIV or HCV statuses. Planning to move to the US is associated with knowing PWID who have moved or plan to move, negatively associated with age, and is not associated with HIV or HCV status. Around one third of those that lived in the US reported having some sort of support, with the majority receiving support from family sources. No participant received help to enter HIV/HCV treatment.

Conclusions: A multi-region approach to prevention is required to make a dent in curbing HIV/HCV transmission in this population. Understanding PWID migration patterns, risk behaviors, and health care needs in the US is now more important than ever as natural disasters prompted by human-made climate change will only increase in the future, raising demands not only for service providers but also harm reduction policies to cope with an increasing influx of "climate refugees" as PWID move across national borders.
\end{abstract}

Keywords: Migration, PWID, Puerto Rico, Continental US, Epidemiological bridge, HIV, Harm reduction

\footnotetext{
* Correspondence: rabadie2@unl.edu

1 Department of Sociology, University of Nebraska-Lincoln, 206 Benton Hall,

Lincoln, NE 68588, USA

Full list of author information is available at the end of the article
}

(c) The Author(s). 2019 Open Access This article is distributed under the terms of the Creative Commons Attribution 4.0 International License (http://creativecommons.org/licenses/by/4.0/), which permits unrestricted use, distribution, and reproduction in any medium, provided you give appropriate credit to the original author(s) and the source, provide a link to the Creative Commons license, and indicate if changes were made. The Creative Commons Public Domain Dedication waiver (http://creativecommons.org/publicdomain/zero/1.0/) applies to the data made available in this article, unless otherwise stated. 


\section{Background}

Migration increases the risk of HIV and hepatitis C (HCV) transmission among people who inject drugs (PWID). When people with HIV and HCV migrate, they carry their viruses with thesm, creating what Rachlis and colleagues have termed an "epidemiological bridge" between the territory they leave and the new one they encounter [42]. Migrant individuals might serve as a bridge to Infectious diseases from high-risk to low-risk individuals and from high-prevalence areas to new locations with low prevalence $[57,58]$.

In addition, migration disrupts the social networks for habitual injection that PWID rely on to acquire and use drugs, placing them and their co-injecting partners at risk. Migration also introduces PWID into environments that might be culturally difficult to navigate for newcomers, enhancing participation in risk practices $[46,54]$. Numerous studies show that migrant PWID engage in different risk behaviors when compared to the native population, including using drugs at a higher frequency and relying on medical treatment less often $[19,50]$. Borders facilitate migrant movements, constituting a particular fertile field for the transmission of HIV/HCV among PWID [29, 44]. Studies conducted in the city of Tijuana, on the MexicoUS border, show how migration contributed to increase the risk of HIV/HCV transmission among PWID $[39,56]$.

Unlike most migrants to the US, Puerto Ricans are US citizens, having first been brought to Hawaii as laborers in the plantation economy more than 100 years ago [52]. Mass migration only started after commercial aviation became more available in the post-war era. Initially, migrants settled mainly in New York City (NYC) and the northeast, with some concentration in Chicago $[15,16]$. Decades of migration fueled by economic crises and natural disasters have resulted in more Puerto Ricans living in the continental US than on the island, a movement that only seems to have intensified after Hurricane Maria hit the island in 2017 [34].

Puerto Rican PWID are a part of this migration movement, variously seeking family reunification, economic opportunities, and addiction and/or HIV/HCV treatment options. Migrant PWID who started injecting drugs in Puerto Rico tend to engage in different risk practices in the continental US than their non-migrant PWID counterparts. A study by Gelpí-Acosta and colleagues showed that migrant PWID from Puerto Rico presented higher injection and sexual risk behaviors along with higher HCV prevalence than their US-born PWID counterparts in NYC [21]. Another study of PWID of Puerto Rican origin living in New York and New Jersey found similarly that this group tends to inject frequently and engage in sexual risk behaviors, and that being born in Puerto Rico and purchasing drugs jointly with other users were accurate predictors of injection risks $[11,14]$.
In addition, family reunification has been identified as an important factor motivating migration among metropolitan Puerto Rican PWID [13].

While these studies make significant contributions towards understanding the relationship between migration and risk behaviors, and shed light on migration motivations among metropolitan Puerto Rican PWID, the range of factors influencing their migration to the US and the resources they draw on to do so are not well understood. This is particularly true for rural Puerto Rican PWID, and the present study is the first empirical research to document migration patterns among this population. The specificities of their migration raise important challenges that need to be documented in order to implement more effective harm reduction policies at home (Puerto Rico) and abroad (US). To begin to address these challenges, this paper examines factors motivating migration and sources of support.

\section{Methods \\ Sample}

Surveys were administered to 315 PWID between April and June 2015 in four rural municipalities of Puerto Rico, located approximately 15-30 miles south of San Juan. Eligible participants had to be alert, be 18 years or older, and have injected drugs within the last 30 days. For convenience, interviews were conducted by a trained ethnographer, alongside Puerto Rican staff working out of a storefront in one of the four municipalities, and in close coordination with the region's only syringeexchange program (SEP).

\section{Recruitment}

Respondent-driven sampling was used to recruit participants. Respondent-driven sampling is often preferred for hidden and hard-to-reach populations [22]; details about the recruitment process in this study have been published elsewhere [9]. We recruited two PWID ("seeds") in each of the four municipalities, and after they completed the survey were given three referral coupons to pass out to other PWID from their networks to potentially join the study. Participants could earn an additional \$10 for every referral that completed the survey. In a respondent driven framework the interviewer is never aware of the people who may have been given a coupon and refused an interview. In this framework traditional response rate calculations are not applicable. However, the anonymity this provides to potential participants is one of the reasons it is preferred for recruitment of hidden an hard-to-reach populations $[23,26]$.

\section{Consent and compensation}

All participants gave consent prior to data collection. After completing the questionnaire, participants were 
paid $\$ 25$. Ethical clearance was secured from the institutional review boards of the University of NebraskaLincoln (IRB\# 20131113844FB) and the University of Puerto Rico (IRB\# A8480115) prior to data collection.

\section{Measures}

The questionnaire was administered by the interviewer, and was based on the CDC National HIV and Behavioral Surveillance (NHBS) of Injection Drug Users Round 3 Questionnaire version 13 (https://www.cdc.gov/hiv/statistics/systems/nhbs/operations.html). This version of the questionnaire is designed to produce regular estimates of the number of PWID and their behaviors in 23 urban areas in the US, one of which is the city of San Juan, Puerto Rico, which is north of four rural villages surveyed in the present research. In addition, the project provided rapid blood testing for HIV and HCV using INSTI Rapid HIV antibody tests (Biolytical Laboratories) and OraQuick HCV Rapid antibody tests (OraSure Technologies). Participants who tested positive for HIV or HCV antibodies were offered referral and transportation to a primary care doctor for confirmatory testing and link-to-care.

\section{Measures \& analytic strategy}

The primary dependent variables for this paper are: the number of times a person has lived in the continental US which is a self-reported count, and if they are planning on moving to the continental US in the future where a "yes" response is coded as 1 , and a "no" response as " 0 ." We use a multivariable negative binomial regression model to test for associations between the number of times a person has lived in the continental US and the participant's characteristics. This type of statistical model is appropriate for count outcomes which are over dispersed and do not have a heavy concentration of zeros [30]. Results from the negative binomial regression are discussed in terms of the percent change of the expected number of times a person has lived in the continental US in association with their individual characteristics. Multivariable logistic regression is used to test for associations between participant's future plans to move to the continental US and their current characteristics. This type of model is appropriate for outcomes that are binary (e.g. can only take the value of 0 or 1 ) [30]. Results from these models are discussed in terms of percent change in the ratio of the odds that a participant is planning on moving to the continental US and their current characteristics.

In all models, we use the participant's self-reported HIV and HCV status. Participants could have a selfreported unknown, negative, or positive status. This reflects the results of their more recent test prior to our interview. An unknown report occurs when the participant has never been tested. We use this measure and not the results of the antibody test administered during our interview because we are interested in how their behavior is associated with their own understanding of their HIV or HCV status, and not the results of a test they just completed. For both HIV and HCV we use the self-reported negative category as the reference in the analytical models. The final analytical sample for this paper is 296, with 19 participants removed from the sample due to missing data.

\section{Results}

Our sample is largely male (90.2\%), and average 42 years of age (Table 1). The participants are extremely poor, with only $10.5 \%$ reporting earning more than $\$ 10,000$ annually. As many as $47 \%$ did not complete high school, while the rest either completed high school $(34.5 \%)$ or went beyond high school (18.9\%). Approximately 47\% were single; $31 \%$ were either separated, divorced or widowed; and about $22 \%$ were cohabiting with or married to another person.

Table 1 shows relevant HIV data: 14.5\% of participants reported never being tested, $81.4 \%$ had recently tested negative, and only $4.1 \%$ had recently tested positive. HCV data include that 23.3\% had never been tested, $27 \%$ had recently tested negative, and $49.7 \%$ had recently tested positive. Migration is a significant phenomenon among these rural PWID, with $75.3 \%$ reporting knowing other PWID who either plan to or have already moved to the continental US. Moreover, $64.9 \%$ reported ever living in the continental US. The average participant had migrated to the continental US 1.26 times, with some participants reporting up to 20 migration events to the US mainland. Additionally, 49\% reported "planning to migrate to the continental US" in the future.

Table 2 presents factors associated with the number of times participants have lived in the continental US. Those who completed high school had $1.40(p<0.05)$ more migration events, and those with education beyond high school had $1.47(\mathrm{p}<0.05)$ more migration events than those with less than high school. Whilst educational attainment was associated with migration events, so too was older age. In fact, every year increase in age is associated with a $2 \%(p<0.01)$ increase in the expected migration event count. Marital status, income, and knowing other PWID who have already moved or plan to move to the continental US were not associated with migration events. Those who had never been tested for HIV were associated with $47 \%(p<0.05)$ lower expected migration events than those with HIV-negative status. We found no difference in the migration counts between those with a negative self-reported HIV status and a positive self-reported HIV status. There were no associations between self-reported $\mathrm{HCV}$ status and the number of times a participant has lived in the continental US. 
Table 1 Descriptive Statistics $(n=296)$

\begin{tabular}{|c|c|c|c|c|}
\hline Variable & $\% /$ Mean & Std. Dev. & Min & Max \\
\hline Female & $10 \%$ & & 0 & 1 \\
\hline Age & 41.9 & 10.1 & 18 & 70 \\
\hline Income 10 k+ & $10 \%$ & & 0 & 1 \\
\hline \multicolumn{5}{|l|}{ Education } \\
\hline Less than HS & $46.96 \%$ & & 0 & 1 \\
\hline $\mathrm{HS}$ & $34.46 \%$ & & 0 & 1 \\
\hline More than HS & $18.58 \%$ & & 0 & 1 \\
\hline \multicolumn{5}{|l|}{ Marital Status } \\
\hline Single & $47.3 \%$ & & 0 & 1 \\
\hline Sep/Div/Widowed & $31.1 \%$ & & 0 & 1 \\
\hline Together & $21.6 \%$ & & 0 & 1 \\
\hline $\begin{array}{l}\text { Know other PWID who Have Moved or Plan to } \\
\text { Move to Continental US }\end{array}$ & $75.3 \%$ & & 0 & 1 \\
\hline \multicolumn{5}{|l|}{ HIV: Most Recent Status } \\
\hline Never Tested (Unknown) & $14.5 \%$ & & 0 & 1 \\
\hline Negative & $81.4 \%$ & & 0 & 1 \\
\hline Positive & $4.1 \%$ & & 0 & 1 \\
\hline \multicolumn{5}{|l|}{ HCV: Most Recent Status } \\
\hline Never Tested (Unknown) & $23.3 \%$ & & 0 & 1 \\
\hline Negative & $27.0 \%$ & & 0 & 1 \\
\hline Positive & $49.7 \%$ & & 0 & 1 \\
\hline Previously Lived in the Continental US & $64.9 \%$ & & 0 & 1 \\
\hline Number of Times Lived in the Continental US & 1.26 & 2.00 & 0 & 20 \\
\hline Planning on Moving to Continental US & $49.0 \%$ & & 0 & 1 \\
\hline
\end{tabular}

In Table 3 we present associations with the variable having plans to migrate to the continental US in the future. In contrast to the number of times participants have lived in the continental US, here education measures were not associated with plans to migrate, and the odds of a participant planning on migrating decreased by $4 \%(p<0.05)$ per year of older age. Participants who were separated, divorced, or widowed were associated with $1.97(p<0.05)$ times the odds of planning to migrate compared to single participants. In addition, knowing other PWID who had already moved or were planning to move was associated with a $142 \%(p<0.01)$ increase in the odds of the participant planning on migrating. Having previously lived in the continental US was also associated with higher odds of planning on migrating in the future, and increase of $71 \%(\mathrm{p}<0.05)$. We found no other differences in the odds of planning to migrate to the continental US by any other measure.

In Table 4 we present the types of organizations and support received by participants to migrate to the continental US in the past. Overall, of the $65 \%$ participants with past migration events, only $29.5 \%(n=57)$ had received any type of support in Puerto Rico for their move.
Most often, participants received support from "family and friends" (61.4\%), "other" (22.8\%), and "municipal police" (10.5\%); the most common type of support came in the form of a "plane ticket" (71.9\%), followed by "financial" (36.8\%). No participants reported receiving direct connections to HIV or HCV treatment programs.

\section{Discussion}

This paper explores influential factors of migration to the continental US among rural Puerto Rican PWID. Our findings confirm what other Puerto Rican PWID researchers $[7,8]$ and Puerto Rican diaspora scholars [17] have found: US-bound migration is a significant phenomenon among rural Puerto Rican PWID, with $65 \%$ reporting that they have lived in the US. The study population shares another important trait with the circular migration patterns of Puerto Ricans to the US: many have lived in the US more than once $[3,45]$. While being with family or seeking to improve one's economic chances spur many in the larger Puerto Rican diaspora to migrate to the US [51], there may be other influential factors behind the decision. We found that factors such as higher education and older age were 
Table 2 Multivariable Negative-Binomial Regression of the Number of Times Lived in in the Continental US

\begin{tabular}{|c|c|c|c|c|}
\hline \multirow{2}{*}{$\frac{\text { Variable }}{\text { Female }}$} & \multirow{2}{*}{$\frac{\text { IRR }}{1.11}$} & \multirow[t]{2}{*}{$\mathrm{P}$} & \multicolumn{2}{|c|}{$95 \% \mathrm{Cl}$} \\
\hline & & & 0.7 & 1.7 \\
\hline Age & 1.02 & $* *$ & 1.0 & 1.0 \\
\hline Income 10 k+ & 1.24 & & 0.8 & 1.9 \\
\hline \multicolumn{5}{|l|}{ Education } \\
\hline Less than HS & Reference & & & \\
\hline $\mathrm{HS}$ & 1.40 & * & 1.0 & 1.9 \\
\hline More than HS & 1.47 & * & 1.0 & 2.1 \\
\hline \multicolumn{5}{|l|}{ Marital Status } \\
\hline Single & Reference & & & \\
\hline Sep/Div/Widowed & 0.86 & & 0.6 & 1.2 \\
\hline Together & 1.19 & & 0.8 & 1.7 \\
\hline Know other PWID who Have Moved or Plan to Move to Continental US & 0.89 & & 0.6 & 1.2 \\
\hline \multicolumn{5}{|l|}{ HIV: Most Recent Status } \\
\hline Never Tested (Unknown) & 0.53 & * & 0.3 & 0.9 \\
\hline Negative & Reference & & & \\
\hline Positive & 1.04 & & 0.5 & 2.0 \\
\hline \multicolumn{5}{|l|}{ HCV: Most Recent Status } \\
\hline Never Tested (Unknown) & 1.50 & & 1.0 & 2.3 \\
\hline Negative & Reference & & & \\
\hline Positive & 1.16 & & 0.8 & 1.6 \\
\hline Intercept & 0.40 & * & 0.2 & 0.8 \\
\hline Psuedo-R^2 & 0.03 & & & \\
\hline N & 296 & & & \\
\hline
\end{tabular}

${ }^{*} p<0.05,{ }^{* *} p<0.01,{ }^{* * *} p<0.001$

positively correlated with having past migration events. In addition, just like their metropolitan counterparts [36, 48], rural Puerto Rican PWID also record multiple migration events.

Other factors associated with migration include "having lived previously in the US" and "knowing somebody that did." These factors increase the odds of planning to migrate to the US. Arguably, these factors suggest the powerful draw of family and other social networks, which could enhance or limit migration possibilities. The composition of PWID's social networks could enhance migration plans, as having friends or family in the continental US may facilitate plans to moving to the US. Also, "having lived previously in the US" is arguably indicative of having established social networks abroad. The migration literature is replete with examples of social networks and even immigrant enclaves seamlessly enhancing migration $[5,33,49]$. Interestingly, here we found an inverse relationship to that of past migration events. While education and age were positively associated with "past migration events," here these factors either not associated with plans to migrate (education) or are negatively associated with planning to migrate (age).
It is possible that the latter may be a result of "migration exhaustion," at the end of a cycle of circular migration between the homeland and the mainland, as older PWID recorded a significantly higher number of past migration events.

The lack of statistical relationship between selfreported $\mathrm{HIV} / \mathrm{HCV}$ statuses and past or future migration events is noteworthy, and could mean that migration is not associated (or at least not enough) by the presence of infectious diseases. Despite a paucity of health care resources on the island [24, 31, 37], HIV patients are covered by La Reforma, the local version of Medicare/Medicaid, as are those co-infected by HIV and HCV. Despite the fact that HCV treatment is not covered by La Reforma in Puerto Rico and most PWID go untreated since they cannot afford private coverage [1], seeking HCV care in the continental US does not seem to be among their motivations. This finding may appear striking, for many might presume that the dearth of treatment services available in rural Puerto Rico might be a big motivator for migrating to the continental US. Yet, our findings show that even for those who are $\mathrm{HCV}$-positive (a considerably larger subgroup 
Table 3 Multivariable Logistic Regression of Plans to Move to the Continental US

\begin{tabular}{|c|c|c|c|c|}
\hline Variable & OR & $P$ & $95 \% \mathrm{Cl}$ & \\
\hline Female & 1.30 & & 0.57 & 2.96 \\
\hline Age & 0.96 & $* *$ & 0.94 & 0.99 \\
\hline Income 10 k+ & 1.07 & & 0.48 & 2.36 \\
\hline \multicolumn{5}{|l|}{ Education } \\
\hline Less than HS & Reference & & & \\
\hline HS & 0.59 & & 0.34 & 1.04 \\
\hline More than HS & 0.68 & & 0.35 & 1.34 \\
\hline \multicolumn{5}{|l|}{ Marital Status } \\
\hline Single & Reference & & & \\
\hline Sep/Div/Widowed & 1.97 & * & 1.09 & 3.55 \\
\hline Together & 1.59 & & 0.84 & 3.01 \\
\hline $\begin{array}{l}\text { Know other PWID who Have Moved or } \\
\text { Plan to Move to Continental US }\end{array}$ & 2.42 & $* *$ & 1.34 & 4.36 \\
\hline \multicolumn{5}{|l|}{ HIV: Most Recent Status } \\
\hline Never Tested (Unknown) & 1.16 & & 0.54 & 2.50 \\
\hline Negative & Reference & & & \\
\hline Positive & 0.76 & & 0.22 & 2.68 \\
\hline \multicolumn{5}{|l|}{ HCV: Most Recent Status } \\
\hline Never Tested (Unknown) & 0.64 & & 0.31 & 1.34 \\
\hline Negative & Reference & & & \\
\hline Positive & 0.60 & & 0.34 & 1.08 \\
\hline Previously Lived in Continental US & 1.71 & * & 1.01 & 2.91 \\
\hline Intercept & 2.23 & & 0.60 & 8.31 \\
\hline Psuedo- $R \wedge 2$ & 0.07 & & & \\
\hline N & 296 & & & \\
\hline
\end{tabular}

${ }^{*} p<0.05,{ }^{* *} p<0.01,{ }^{* * *} p<0.001$

Table 4 Types of Support PWID Had for Moving to Continental US in the Past $(n=57)$

\begin{tabular}{ll}
\hline Variable & $\%$ \\
\hline Received Any Support For Migration & $29.5 \%$ \\
Types of Organizations That Provided Support (Not Mutually Exclusive) \\
Pastor/Church/Religious Org. & $3.5 \%$ \\
State Police & $5.3 \%$ \\
Municipal Police & $10.5 \%$ \\
Family/Friends & $61.4 \%$ \\
Other & $22.8 \%$ \\
Types of Support Received (Not Mutually Exclusive) & \\
Financial & $36.8 \%$ \\
Purchased Plane Ticket & $71.9 \%$ \\
Direct Connection to HIV/AIDS Program & $0.0 \%$ \\
Direct Connection to HCV Program & $0.0 \%$ \\
Direct Connection to Drug Treatment Programs & $21.1 \%$ \\
Other & $12.3 \%$ \\
\hline
\end{tabular}

than those with HIV), accessing treatment (in the US) is not at the forefront of their priorities. Other studies have found that HCV does not concern PWID as much as HIV does [2, 47, 55], and this may be a plausible explanation for this finding.

Finally, our findings on the sources of support and the types of support contain a surprising aspect: most migrants in our study do not have any sources of support (69.5\%). This is remarkable given that much of the literature on migrant Puerto Rican PWID traces how family and other types of networks create bridges between the US and PR. Of the $29.5 \%$ that lived in the US in the past and reported having some sort of support, the majority received support from family. Other sources of support were municipal or state police, and religious organizations. While we only have limited data on these sources of support, it is noteworthy that this is the first time a study has identified these other sources as influential in the migration phenomenon. In addition, the most common form of support (for migration) is a "plane ticket" (around 2/3), usually one-way. 
Unlike undocumented PWID from other Latin American origins, Puerto Rican PWID are US citizens, free to move back and forth between the motherland and the mainland. US-citizenship is perhaps the most important migration enhancer, even in the absence of other sources of support for migration. To borrow Deren's terminology (2007), this "airbridge" between the US and PR raises important questions about the epidemiological bridge, risk behaviors, and prevention among Puerto Rican PWID enmeshed in this circular migration. A multi-region approach to prevention is required if we were to make a dent in curbing $\mathrm{HIV} / \mathrm{HCV}$ transmission in this population $[12,29,38]$. While health policies and, in particular, harm-reduction interventions have effectively addressed the link between HIV transmission and migration processes $[10,25,28,32,40,59]$, the health challenges posed by migrating PWID have not received the same degree of attention. An exception is the work conducted by Strathdee and colleagues $[53,54]$ in Tijuana, on the Mexican side of the Mexico-US border, which draws attention to the HIV/HCV transmission risk created by the combined effects of poverty, migration, forced deportation, and a scarcity of health care resources for this vulnerable population in the region. Harm-reduction programs need to recognize that while PWID have traditionally been as a static population in large urban centers-or more recently rural or suburban communities-they also form part of larger migratory flows [35, 43]. Their movement across national borders creates both challenges and opportunities for health policy interventions.

Understanding PWID migration patterns, risk behaviors, and health care needs in the US is now more important than ever. In September 2017 Hurricane Maria devastated the island, raising additional barriers to medication assisted treatment (MAT), syringe exchange providers (SEP), mental health care, and other services that support PWID in rural areas. It also reinforced a migratory process that had gained strength since the economic crisis that started a decade earlier. As PWID join this migratory trajectory to the mainland, more research is needed to understand their migration patterns, health needs, and HIV/HCV risk behaviors. These issues will become increasingly central to the future harmreduction agenda, as natural disasters prompted by human-made climate change will only increase in the future, raising demands not only for service providers but also public health researchers to cope with an increasing influx of "climate refugees" as PWID move across national borders $[4,6,18,20,27,41]$.

\section{Limitations}

One limitation if this study is data about migratory trajectories among PWID from rural Puerto Rico to the continental United States is based not on direct observation but on participants' recollection. It is possible that responses were affected by recall bias. Subjects might have underestimated the number of times they migrated to the US, or, fail to recall their particular motivations to migrate as well as the resources mobilized in order to migrate. Despite this limitation, we are confident that the data presented represent a significant contribution to an under studied problem.

\section{Conclusions}

Findings suggest that the migration of rural PWID living in Puerto Rico to the continental US is relatively high, with more than half of the sample reporting that they had lived in the US at least at one point in time. Having lived previously in the US and knowing somebody that still did increased the odds that a respondent had lived in the US. Around one-third of those that lived in the US reported having some sort of support, with the majority receiving support from family sources, which reflected goals of family reunification, while one-fifth were linked to a drug treatment program. Finally, there was no relationship between $\mathrm{HIV} / \mathrm{HCV}$ self-reported status and having lived in the US, and no participant received help to enter HIV/ HCV treatment. Migration of PWID in Puerto Rico to the continental US is likely to increase in the future, driven by economic factors and natural disasters, calling for the design of public health policies to address prevention and treatment needs in this population.

\section{Abbreviations \\ HCV: Hepatitis C Virus; HIV: Human Inmunodeficiency Virus; MAT: Medically Assisted Treatment; NYC: New York City; PWID: People Who Inject Drugs;} SEP: Syringe Exchange Providerss; US: United States

\section{Acknowledgments}

Thanks to all the participants in our study. Without their cooperation this study would not have been possible. We also want to acknowledge our research assistants, Carmen Ana Davila and Angelica Rivera.

\section{Authors' contributions}

RA collected the data and wrote the draft paper, $\mathrm{PH}$ conducted the statistical analysis and interpreted the results, CGA revised the manuscript and improved the language, KD designed the study. The author read and approved the final manuscript.

\section{Funding}

This work was supported by the National Institute on Drug Abuse of the National Institutes of Health [grant number R01DA037117]. The content is solely the responsibility of the authors and does not necessarily represent the official views of the National Institutes of Health. The funding agency did not play any role in the design of the study, collection of data, analysis, interpretation of data, and writing of the manuscript. Additional support was received from the National Institute of General Medical Sciences at NIH [grant number P20GM130461].

Availability of data and materials

All data generated or analysed during this study are included in this published article [and its supplementary information files].

Ethics approval and consent to participate

The study was approved by the IRBS of the University of Nebraska-Lincoln and the University of Puerto Rico. Written informed consent was obtained from all subjects. 


\section{Consent for publication}

Not applicable.

\section{Competing interests}

The authors declare that they have no competing interests.

\section{Author details}

'Department of Sociology, University of Nebraska-Lincoln, 206 Benton Hall, Lincoln, NE 68588, USA. ${ }^{2}$ Social Science Department, LaGuardia Community College, 29-10 Thompson Avenue, Long Island City, NY 11101, USA.

Received: 31 May 2019 Accepted: 4 December 2019

Published online: 19 December 2019

\section{References}

1. Abadie R, Abadie R. To enroll or not to enrolll: a researcher struggles with the decision to involve study participants in a clinical trial that could save their lives. Narrative Inquiry in Bioethics. 2017;7(1):71-7. https://doi.org/10. 1353/nib.2017.0019

2. Abadie R, Welch-lazoritz M, Khan B, Dombrowski K. Addictive behaviors reports social determinants of HIV / HCV co-infection : a case study from people who inject drugs in rural Puerto Rico. Addict Behav Rep. 2017;5:29-32. https://doi. org/10.1016/j.abrep.2017.01.004

3. Acevedo G. Neither here nor there: Puerto rican circular migration. In Immigrants and Social Work: Thinking Beyond the Borders of the United States; 2013. https://doi.org/10.4324/9781315043999.

4. Biermann F, Boas I. Preparing for a warmer world: towards a global governance system to protect climate refugees. Glob Environ Polit. 2010. https://doi.org/10.1162/glep.2010.10.1.60.

5. Boyd M. Family and personal networks in international Migration: Recent Developments and New Agendas. Int Migr Rev. 2006. https://doi.org/10. 2307/2546433

6. Cepeda A, Valdez A, Kaplan C, Hill LE. Patterns of substance use among hurricane Katrina evacuees in Houston, Texas. Disasters. 2010;34(2):426-46.

7. Colon HM, Deren S, Robles RR, Kang S-Y, Cabassa M, Sahai H. A comparative study of mortality among Puerto Rican injection drug users in East Harlem, New York, and Bayamon, Puerto Rico. J Urban Health. 2006;83(6):1114-26. https://doi.org/10.1007/s11524-006-9088-8

8. Colón HM, Robles RR, Deren S, Sahai H, Finlinson HA, Andía J, et al. Between-city variation in frequency of injection among Puerto Rican injection drug users: East Harlem, New York, and Bayamon, Puerto Rico. J Acquired Immune Deficiency Syndromes (1999). 2001;27(4):405-13.

9. Coronado-Garcia M, Thrash CR, Welch-Lazoritz M, Gauthier R, Reyes JC, Khan B, Dombrowski K. Using network sampling and recruitment data to understand social structures related to community health in a population of people who inject drugs in rural Puerto Rico. P R Health Sci J. 2017;36(2):77-83.

10. Deb AK, Deb M, Saha MK, Chakraborty S, Bhattacharya SK, Detels R. HIV transmission potential among local and migrant factory workers in Kolkata, India. AIDS Behav. 2009. https://doi.org/10.1007/s10461-009-9542-1.

11. Deren S, Oliver-Velezl D, Finlinson A, Robles R, Andia J, Colón HM, et al. Integrating qualitative and quantitative methods: comparing HIV-related risk behaviors among Puerto Rican drug users in Puerto Rico and New York. Subst Use Misuse. 2003. https://doi.org/10.1081/JA-120016563.

12. Deren S, Gelpí-Acosta C, Albizu-García CE, González Á, Des Jarlais DC, Santiago-Negrón S. Addressing the HIV/AIDS epidemic among puerto rican people who inject drugs: the need for a multiregion approach. Am J Public Health. 2014. https://doi.org/10.2105/AJPH.2014.302114.

13. Deren S, Kang SY, Colón HM, Robles RR. The Puerto Rico-New York airbridge for drug users: description and relationship to HIV risk behaviors. J Urban Health. 2007. https://doi.org/10.1007/s11524-006-9151-5.

14. Deren S, Kang SY, Mino M, Guarino H. Migrant drug users: predictors of HIVrelated sexual and injection risk behaviors. J Immigr Minor Health. 2010. https://doi.org/10.1007/s10903-008-9218-3.

15. Duany J, Torre C, RodríguezVecchini H, Burgos W. The commuter nation: perspectives on Puerto Rican migration. Revista de Ciencias Sociales; 1996.

16. Duany J. The Orlando Ricans: overlapping identity discourses among middle-class Puerto Rican immigrants. Cent J. 2010;22(1):85-115.

17. Duany J. Puerto Rico, migration 1868 to present. Encyclopedia Global Human Migr. 2013. https://doi.org/10.1002/9781444351071.wbeghm428.
18. Farbotko C, Lazrus $H$. The first climate refugees? Contesting global narratives of climate change in Tuvalu. Glob Environ Change. 2012. https:/doi.org/10.1016/j. gloenvcha.2011.11.014

19. Folch C, Casabona J, Espelt A, Majó X, Meroño M, Gonzalez V, et al. High prevalence and incidence of HIV and HCV among new injecting drug users with a large proportion of migrants - is prevention failing? Subst Use Misuse. 2016. https://doi.org/10.3109/10826084.2015.1092991.

20. Friedman SR, Rossi D, Braine N. Theorizing "big events" as a potential risk environment for drug use, drug-related harm and HIV epidemic outbreaks. Int J Drug Policy. 2009. https://doi.org/10.1016/j.drugpo.2008.10.006.

21. Gelpí-Acosta C, Pouget ER, Reilly KH, Hagan H, Neaigus A, Wendel T, Marshall DM. Time since migration and HIV risk behaviors among Puerto Ricans who inject drugs in New York City. Substance Use Misuse. 2016;51: 870-81. https://doi.org/10.3109/10826084.2016.1155616.

22. Heckathorn DD. Respondent-driven sampling II: deriving valid population estimates from chain-referral samples of hidden populations. Soc Probl. 2002:49(1):11.

23. Heckathorn DD, Cameron CJ. Network sampling: from snowball and multiplicity to respondent-driven sampling. Annu Rev Sociol. 2017;43(1): 101-19. https://doi.org/10.1146/annurev-soc-060116-053556.

24. Hernández D, Castellón PC, Fernández Y, Torres-Cardona FA, Parish C, Gorshein D, et al. When "the cure" is the risk: understanding how substance use affects HIV and HCV in a layered risk environment in San Juan, Puerto Rico. Health Educ Behav. 2017. https://doi.org/10.1177/1090198117728547.

25. Hirsch JS, Higgins J, Bentley ME, Nathanson CA. The social constructions of sexuality: marital infidelity and sexually transmitted disease - HIV risk in a Mexican migrant community. Am J Public Health. 2002. https:/doi.org/10.2105/AJPH.92.8.1227.

26. Johnston LG, Chen Y-H, Silva-Santisteban A, Raymond HF. An empirical examination of respondent driven sampling design effects among HIV risk groups from studies conducted around the world. AIDS Behav. 2013;17(6): 2202-10. https://doi.org/10.1007/s10461-012-0394-8.

27. Kotarba JA, Fackler J, Johnson BD, Dunlap E. The melding of drug markets in Houston after Katrina: dealer and user perspectives. Subst Use Misuse. 2010;45(9): 1390-405.

28. Kramer MA, Van Veen MG, Op De Coul ELM, Geskus RB, Coutinho RA, Van De Laar MJW, Prins M. Migrants travelling to their country of origin: a bridge population for HIV transmission? Sex Transm Infect. 2008. https://doi. org/10.1136/sti.2008.032094.

29. Li L, Assanangkornchai S, Duo L, McNeil E, Li J. Cross-border activities and association with current methamphetamine use among Chinese injection drug users (IDUs) in a China-Myanmar border region. Drug Alcohol Depend. 2014. https://doi.org/10.1016/j.drugalcdep.2014.01.021.

30. Long JS. Regression models for categorical and limited dependent variables. Thousand Oaks: SAGE Publications, Inc:; 1997.

31. López LM, de Saxe Zerden L, Bourgois P, Hansen H, Abadie R, Dombrowski K, Curtis R. HIV/AIDS in Puerto Rican people who inject drugs: policy considerations. Am J Public Health. 2015;105(1):e3. https://doi.org/10.2105/AJPH.2014.302387.

32. Lurie MN, Williams BG, Zuma K, Mkaya-Mwamburi D, Garnett GP, Sturm AW, et al. The impact of migration on HIV-1 transmission in South Africa: a study of migrant and nonmigrant men and their partners. Sex Transm Dis. 2003. https://doi.org/10.1097/00007435-200302000-00011.

33. MacDonald JS, MacDonald LD. Chain migration ethnic neighborhood formation and social networks. Milbank Mem Fund Q. 2006. https://doi.org/10.2307/3348581.

34. Meléndez E, Hinojosa J. Estimates of Post-Hurricane Maria Exodus from Puerto Rico. In: Centro Voices; 2017.

35. Melo JS, Mittal ML, Horyniak D, Strathdee SA, Werb D. Injection drug use trajectories among migrant Populations: A Narrative Review. Subst Use Misuse. 2018. https://doi.org/10.1080/10826084.2017.1416404.

36. Mino M, Deren S, Sung YK. Social support and HIV-related injection risk among Puerto Rican migrant and nonmigrant injection drug users recruited in New York City. AIDS Educ Prev. 2006. https://doi.org/10.1521/aeap.2006.18.1.81.

37. Mulligan JM. Unmanageable care: an ethnography of health care privatization in Puerto Rico. In: Unmanageable Care: An Ethnography of Health Care Privatization in Puerto Rico; 2014.

38. Ojeda VD, Burgos JL, Rangel MG, Lozada R, Vera A. U.S. drug use and migration experiences of Mexican female sex workers who are injection drug users. Journal of health care for the poor and underserved. 2012. https://doi.org/10.1353/hpu.2012.0177.

39. Ojeda VD, Robertson AM, Hiller SP, Lozada R, Cornelius W, Palinkas LA, et al. A qualitative view of drug use behaviors of Mexican male injection drug users deported from the United States. J Urban Health. 2011. https://doi. org/10.1007/s11524-010-9508-7. 
40. Platt L, Grenfell P, Fletcher A, Sorhaindo A, Jolley E, Rhodes T, Bonell C. Systematic review examining differences in HIV, sexually transmitted infections and health-related harms between migrant and non-migrant female sex workers. Sex Transm Infect. 2013. https://doi.org/10.1136/sextrans-2012-050491.

41. Pouget ER, Sandoval M, Nikolopoulos GK, Friedman SR. Immediate impact of hurricane Sandy on people who inject drugs in New York City. Subst Use Misuse. 2015;50(7):878-84. https://doi.org/10.3109/10826084.2015.978675.

42. Rachlis B, Brouwer KC, Mills EJ, Hayes M, Kerr T, Hogg RS. Migration and transmission of blood-borne infections among injection drug users: understanding the epidemiologic bridge. Drug Alcohol Depend. 2007;90: 107-19. https://doi.org/10.1016/j.drugalcdep.2007.03.014.

43. Rachlis BS, Wood E, Li K, Hogg RS, Kerr T. Drug and HIV-related risk behaviors after geographic migration among a cohort of injection drug users. AIDS Behav. 2010. https://doi.org/10.1007/s10461-008-9397-x.

44. Rafful C, Melo J, Medina-Mora ME, Rangel G, Sun X, Jain S, Werb D. Crossborder migration and initiation of others into drug injecting in Tijuana, Mexico. Drug Alcohol Rev. 2018. https://doi.org/10.1111/dar.12630.

45. Ramos FA. Out-Migration and Return Migration of Puerto Ricans. Immigration and the Workforce: Economic Consequences for the United States and Source Areas, (January); 1992. p. 49-66.

46. Rhodes T. Risk environments and drug harms: a social science for harm reduction approach. Int J Drug Policy. 2009. https://doi.org/10.1016/j.drugpo.2008.10.003.

47. Rhodes T, Treloar C. The social production of hepatitis C risk among injecting drug users: a qualitative synthesis. Addiction. 2008. https://doi.org/ 10.1111/j.1360-0443.2008.02306.x.

48. Rodríguez H. Emotional bridges to Puerto Rico: migration, return migration, and the struggles of incorporation. Contemp Sociol. 2008;37(1):29-30.

49. Ryan L, Sales R, Tilki M, Siara B. Social networks, social support and social capital: the experiences of recent polish migrants in London. Sociology. 2008. https://doi.org/10.1177/0038038508091622.

50. Saigí N, Espelt A, Folch C, Sarasa-Renedo A, Castellano Y, Majó X, et al. Differences in illegal drug consumption between native and immigrants in a large sample of injected drug users in Catalonia (Spain). Adicciones. 2014;26(1):69-76.

51. Silver P. Remembering Abuela: Memory, authenticity and place in Puerto Rican Orlando. Latino Stud. 2015. https://doi.org/10.1057//st.2015.29.

52. Stinson-Fernandez JH. The Puerto Rican Diaspora: Historical Perspectives. J Am Hist. 2010. https://doi.org/10.2307/4486387.

53. Stockman JK, Strathdee SA. HIV among people who use drugs: a global perspective of populations at risk. J Acquir Immune Defic Syndr. 2010. https://doi.org/10.1097/QAl.0b013e3181f9c04c.

54. Strathdee SA, Lozada R, Pollini RA, Brouwer KC, Mantsios A, Abramovitz DA, et al. Individual, social, and environmental influences associated with HIV infection among injection drug users in Tijuana, Mexico. J Acquir Immune Defic Syndr. 2008a. https://doi.org/10.1097/QAl.0b013e318160d5ae.

55. Treloar $C$, Rhodes $T$. The lived experience of hepatitis $C$ and its treatment among injecting drug users: qualitative synthesis. Qual Health Res. 2009. https://doi.org/10.1177/1049732309341656.

56. Wagner KD, Pollini RA, Patterson TL, Lozada R, Ojeda VD, Brouwer KC, et al. Crossborder drug injection relationships among injection drug users in Tijuana, Mexico. Drug Alcohol Depend. 2011. https:/doi.org/10.1016/.jrugalcdep.2010.08.009.

57. White RG. Commentary: what can we make of an association between human immunodeficiency virus prevalence and population mobility? Int J Epidemiol. 2003. https://doi.org/10.1093/ije/dyg265.

58. Williams ML, Atkinson J, Klovdahl A, Ross MW, Timpson S. Spatial bridging in a network of drug-using male sex workers. J Urban Health. 2005. https:// doi.org/10.1093/jurban/jti022.

59. Zuma K, Gouws E, Williams B, Lurie M. Risk factors for HIV infection among women in Carletonville, South Africa: Migration, demography and sexually transmitted diseases. Int J STD AIDS. 2003. https:/doi.org/10.1258/095646203322556147.

\section{Publisher's Note}

Springer Nature remains neutral with regard to jurisdictional claims in published maps and institutional affiliations.

Ready to submit your research? Choose BMC and benefit from:

- fast, convenient online submission

- thorough peer review by experienced researchers in your field

- rapid publication on acceptance

- support for research data, including large and complex data types

- gold Open Access which fosters wider collaboration and increased citations

- maximum visibility for your research: over $100 \mathrm{M}$ website views per year

At BMC, research is always in progress.

Learn more biomedcentral.com/submissions 